THE DETERMINANTS OF POST-IMMIGRATION INVESTMENTS IN EDUCATION

\author{
by \\ Barry R Chiswick \\ and \\ Paul W Miller \\ DISCUSSION PAPER 92.17 \\ OCTOBER 1992 \\ ISSN 0811-6067 \\ ISBN 0-86422-216-5
}




\section{THE DETERMINANTS OF POST-IMMIGRATION INVESTMENTS IN EDUCATION*}

by

Barry R Chiswick**

Department of Economics

University of Illinois at Chicago

Chicago, IL 60680

USA

and

Paul W Miller

Department of Economics

University of Western Australia

Perth, Western Australia

Australia

\section{DISCUSSION PAPER 92.17}

OCTOBER 1992

* We appreciate the financial support for this project provided by the Bureau of Immigration Research, Australia and, during Barry Chiswick's sabbatical by the Falk Institute for Economic Research in Israel (Jerusalem). The views expressed in this paper do not necessarily represent those of the funding agencies. A preliminary version of some of the analysis contained herein was included in the research report Chiswick and Miller (1992a).

** Co-author responsible for correspondence. 


\section{Abstract}

"The Determinants of Post-Immigration Investments in Education"

Barry R. Chiswick

and

Paul W. Miller

This paper analyzes the determinants of post-migration investments in education by adult immigrants using survey data for Australia. OLS, logit and multinominal logit analyses are employed. Postmigration education is shown to vary negatively with age at arrival and positively with respect to duration in the destination, preimmigration schooling and pre-immigration occupational status. The effects of country of origin and visa category at entry are also analyzed. The positive relation between pre- and post-migration schooling in these data, where both are directly measured, suggests that the "substitute" relation found in studies for the U.S. may be the spurious result of measurement error. 
September 1992

THE DETERMINANTS OF POST-IMMIGRATION INVESTMENTS IN EDUCATION

\section{Introduction}

Research into immigrant labor market performance has shown that the degree of immigrant economic adjustment or assimilation depends in part on the extent of their investment in skills specific to their adopted country. These skills include learning the dominant language of the destination country, acquiring on-thejob training, and receiving formal education.

The formal education that immigrants acquire after arrival augments the skills they bring with them, and this should enhance individual economic performance. Analyzing the determinants and nature of human capital accumulation after arrival is therefore an important step towards understanding the immigrant's adjustment process. Furthermore, from society's point of view skills acquired after arrival differ from those acquired abroad. A country does not finance directly the human capital that its immigrants bring with them, whereas the country generally finances at least part of the costs of human capital acquired after arrival. Ceteris paribus, it would be preferable for the destination country to have immigrants fully trained in the appropriate skills at the time of arrival. In addition, the optimal timing of immigration and schooling investments may warrant post-migration investments. However, where qualifications acquired abroad are not perfectly 
internationally transferable, and where the relative remunerations of occupations differ across countries, there may be advantages to the development of skills after arrival. Moreover, with rising rates of immigration, the demand by immigrants for post-migration schooling is an increasingly important aspect of the overall demand for the product of the education system, and thereby influences the composition of the student body.

Despite the obvious importance of post-immigration schooling to immigrant adjustment, there is very little literature on the topic. This paper expands this skimpy literature through an examination of the determinants of the investment in education after immigration in Australia. Section II reviews the relevant literature on the post-immigration schooling of immigrants. The model of post-migration investments in training is developed in section III. The data used in the estimation of the model, the 1987 Australian survey Labour Force status and other Characteristics of Migrants, are described in section IV. Section $V$ presents the estimation of the model, first focusing on whether any education was acquired after arrival, and then on the specific type of eduction acquired. Section VI is the summary and conclusion.

\section{Literature Review}

There are apparently only two studies of the post-migration investments in schooling by immigrants, and both relied on data for the United States (Table 1).' 
Hashmi (1987) presents an extensive, detailed analysis of two dimensions of the human capital investment decisions by immigrants in the United States, namely the number of years of U.S. schooling acquired and current enrollment status (see Table 1). These are obviously related in that "schooling acquired" represents the cumulative impact of "current enrollment." One dimension represents a flow and the other the stock of post-migration schooling. Both aspects are of interest, however, as the effect of a variable on enrollment may differ from that on attainment (e.g., while enrollments decline with duration of residence, the number of years of schooling would rise). Her analysis is based on two data sets: the 1976 Survey of Income and Education (SIE), and the 1980 U.S. Census of Population. The two measures of post-migration investment and the two data sets studied by Hashmi (1987) yield similar conclusions.

Hashmi shows that post-migration investment is related to preimmigration education, age at arrival, duration in the destination, country of origin, and education price and quality variables. In particular, she finds a negative effect of age at migration on post-immigration schooling, although this effect tends to be less pronounced the greater the age at migration. The impact of preimmigration schooling on post-arrival schooling is also non-linear, and there are some differences between the two data sets Hashmi studied. According to the 1980 U.S. Census, pre-immigration schooling up to the secondary level acts as a complement to the acquisition of U.S. schooling, and pre-immigration post-secondary 
schooling acts as a substitute for post-immigration schooling. In the 1976 SIE, however, pre-immigration schooling up to the Ph.D. or professional level was a substitute for schooling in the U.S.

Duration in the U.S. has a positive non-linear impact on postmigration education and attainment in both data sets Hashmi analyzed. Enrollment rates decrease with duration and cumulative U.S. schooling increases (but at a decreasing rate) with duration. That is, the greatest investments in schooling are made in the early years after immigration.

Considerable differences were found in the amount of investment in post-arrival education across birthplace groups. The strongest findings are in the 1980 Census, which has a larger sample and greater detail on country of birth than the SIE. Immigrants from non-English speaking countries are more likely to invest in education than immigrants from English-speaking countries. Refugees are also found to invest greater amounts in post-migration schooling than non-refugees. ${ }^{2}$ Thus, investments in schooling in the United States are greater the smaller the degree of the transferability of pre-immigration skills.

There is strong evidence in Hashmi's analysis that immigrants from Mexico have relatively low educational achievements in the United states. This is attributable only in part to the presence of illegal immigrants in the data. Investment in U.S.-specific skills may be less profitable for illegal immigrants due to the possibility of apprehension and deportation, and there are some legal difficulties enrolling in school. It appears, however, that 
even legal immigrants from Mexico invest less in U.S. schooling than immigrants from other countries, other things the same.

Hashmi (1987) also reports that there was a negative relationship between schooling investments and the price of schooling, as measured by charges for tuition and fees at the largest public university in the respondent's state of residence. Furthermore, immigrant schooling increased with the quality of education in the state, as measured by the mean score on the Scholastic Aptitude Test in each state. Thus, immigrant enrollment responds to the incentives provided by the price and quality of schooling.

The study by Borjas (1982) has a narrower focus: the smaller sample of male immigrants of Hispanic origin in the $1976 \mathrm{SIE}$, and analyzes only years of post-migration schooling. He found that the Cuban immigrants, primarily refugees with little or no expectation of returning, are more likely to invest in post-migration schooling than are Mexican economic immigrants. Within the Cuban and Mexican samples there is a strong negative relationship between the number of years of education acquired before arrival and the number of years of schooling in the U.S. Borjas' interpretation is that a higher level of pre-immigration schooling raises the price or lowers the benefit of post-arrival education, and hence, foreign and post-immigration schooling are substitutes.

The Hashmi and Borjas studies suffer from several limitations which are intrinsic to the data they analyzed. There are no data on current visa status, motive for migrating or type of visa used 
to enter the U.S. There is therefore no direct mechanism for separately identifying economic migrants, tied movers, refugees and foreign students. Their data also lack a mechanism for identifying occupational status or type of education obtained abroad. 3

Moreover, both studies need to estimate years of schooling in the U.S. as a residual. Data are available in the SIE on total years of schooling and years of schooling at immigration. Postmigration schooling is calculated as total minus pre-immigration schooling. In the 1980 Census, Hashmi estimates post-migration years of schooling from data on total years of schooling and age at migration (current age minus years since migration), and the assumption of continuous school attendance from age 6. Although required by the limitations of the data, to the extent there are purely random errors of measurement in the variables used to calculate post-migration schooling, these procedures impart a negative correlation between measured post-migration schooling and pre-migration schooling. Interruptions in school attendance prior to migration impact a similar negative correlation in the 1980 Census data. Could these factors be responsible for the apparent finding of a substitute (negative) relationship between pre- and post-migration schooling in their studies?

\section{The Model}

It is hypothesized that post-immigration training is determined by the costs and benefits of this training, as related to three sets of explanatory factors. These are pre-immigration 
conditions, the category of admission, and post-migration experiences.

(a) Pre-Immigration Conditions

Pre-immigration conditions can affect the level and transferability of skills that immigrants bring with them. Age at arrival, for example, will affect both the costs of, and returns from, human capital investment. The older the age at arrival the higher the opportunity costs of schooling or training (because of previous investment) and the shorter the duration for benefits from investment in skills specific to the destination labor market.

The international transferability of human capital skills is a function of the similarity between the origin and destination countries (Chiswick 1978, 1979) . As immigrants find their countryof-origin human capital depreciated in the destination labor market, their incentives for post-migration investment would be relatively strong. This incentive derives from the positive effect that destination-country education appears to have on the relevance of origin-country skills to the destination labor market. In other words, "the lower the transferability of skills, the higher the rate of return from investment that increases the transferability" (Hashmi 1987, p. 501), and hence the greater the incentive for investment.

Country-of-origin differences in the propensity for return migration can also influence post-migration incentives for investment. For example, due to the greater proximity and the 
absence of any legal barriers to migration to and from New Zealand, immigrants from New Zealand can be expected to make fewer investments in Australia than otherwise similar immigrants from other English-speaking countries. Cultural attitudes may also differ. For example, it has been noted elsewhere that the aspirations of immigrants in Australia from Southern Europe are often focussed on the educational achievements of their children, rather than upon their own educational attainment (Miller and Volker, 1989).

Pre-immigration educational attainment may be an important determinant of post-arrival investments in human capital. Borjas (1982), for example, uses education acquired abroad as a proxy for income and price effects. He argues that the greater the human capital possessed prior to migration "the more possible it may be to finance further investments in education, but the higher the opportunity costs of investing in further education" (Borjas 1982, p.351). Hashmi (1987), on the other hand, addresses the premigration education variable in terms of the complementarity of schooling in the country of origin with that in the destination, and the substitutability of the two types of schooling. She argues that the complementarity between the two types of education is derived from the greater worker efficiency (i.e., the ability to perform tasks) and greater allocative efficiency (i.e., the ability to make decisions in an optimal manner) on the part of those with more education. 


\section{(b) Class of Admission}

A unique feature of the survey to be analyzed are data on the category of admission into Australia. Immigrants enter Australia under a number of different visa categories, including refugee, principal applicant (sponsored), principal applicant (unsponsored), and the spouse of a principal applicant. The visa category may indicate characteristics of the immigrant that influence investment decisions.

While economic migrants can be expected to be self-selected for skills characterized by high skill transferability, refugees will have skills with less international transferability (Chiswick $1978,1979)$. Due to the often unplanned nature of the migration, refugees acquire little destination-specific knowledge before migration. Moreover, among refugees the probability of gaining asylum in any 'safe' country may be paramount, and the country that maximizes this probability may not be the destination that would maximize the international transferability of skills, ceteris paribus. Furthermore, refugees generally have a lower probability of return migration, in part because the initial move was not voluntary. Thus, it would be expected that refugees make more post-migration investments than economic migrants, ceteris paribus. similarly, tied movers migrate primarily on the basis of kinship ties rather than on the basis on the maximization of their own individual economic well being. It seems reasonable, therefore, that the spouses of principal applicant immigrants will have skills that are less transferable than the skills of economic 
migrants. Tied movers would therefore invest more in education after arrival in Australia, holding constant their expected attachment to the labor market. To the extent they have a lower labor market attachment, however, tied movers would make fewer investments. Thus, it would be expected that female tied movers would make fewer post-migration investments relative to economic migrants than their male counterparts.

\section{c. Post-Migration Experience}

One of the most important aspects of the post-migration experience is duration in the destination. For three reasons postmigration investments will tend to be made earlier in the stay, and diminish with duration. First, to the extent that investments that increase the transferability of pre-migration skills are profitable they tend to have greater returns the sooner they are made. second, there is a rising opportunity cost of time with length of stay, as experience in the country and, in particular, in the labor market raise employment probabilities and wage rates. Third, the longer the delay in investing the shorter the remaining working life in which to receive benefits. While annual propensities to invest would be expected to diminish with duration, the cumulative effect would be an increase with duration in the probability of having acquired a qualification.

Thus, the model of post-immigration educational attainment (POSTEDUC) may be written as:

$\begin{aligned} \text { POSTEDUC }= & \text { f (Age on Arrival, Pre-immigration Education, } \\ & \text { Country of Origin, Pre-immigration Occupation, } \\ & \text { Gender, Migration/Sponsorship Category, Year } \\ & \text { of Arrival). }\end{aligned}$




\section{Description of the Data}

The empirical analysis is based on the 1987 survey, Labour Force and other Characteristics of Migrants conducted by the Australian Bureau of Statistics (ABS). There are several advantages to using these data. First, they provide an analysis of postmigration training for a country other than the United States. Second, unlike surveys for the U.S., data are available on preimmigration occupation and on the type of visa used to enter the country. Third, there are explicit data on both the acquisition of post-migration education and the type of education obtained. Postmigration education need not be estimated, as is necessary in the studies for the United States, as the difference between preimmigration and total schooling.

The survey is restricted to males and females who immigrated to Australia after 1960, were aged 18 or older upon arrival, and had obtained permanent residency status. There are 8,585 immigrants in the sample satisfying these conditions, and the estimated population size for this group is $1,440,095$. Thus, the immigrants in the sample represent 11.8 percent of the civilian population, and almost one-half of all immigrants. The major losses from the immigrant sample arise from the exclusion of those who arrived in 1960 or earlier (one-third of the original sample) and immigrants who arrived as youth (one-sixth of the original sample). The sample includes the most recent immigrants, the group that has received the most attention from the media, researchers and policy makers. 
The post-migration education data are succinctly described by the Australian Bureau of Statistics (1987, p.6):

"Respondents indicated which of the following groups best described their highest qualification held on arrival in Australia and gained since arrival:

(a) Degree: a bachelor degree (including honors), a graduate or post-graduate diploma, masters degree or a doctorate,

(b) Trade Qualification or Apprenticeship: completion of an approved trade/technician apprenticeship in fitting and turning, hair dressing, plumbing, carpentry etc.

(c) Certificate or Diploma: completion of an approved certificate or diploma in secretarial or business studies, administration, teaching, nursing, etc.

(d) other: completion of other types of education, e.g., adult education, preparatory/bridging courses, or hobby courses."

The data released in the public use sample, however, aggregate the 'Certificate or Diploma' and 'other' categories. Thus, in the analysis that follows there are four mutually exclusive categories of post-migration education:

1. Degree,

2. Trade Qualification or Apprenticeship, labelled 'Trade' ,

3. Certificate, Diploma or Other, labelled 'Certificate',

4. No post-arrival education completed, labelled 'Nil'.

Individuals with more than one type of training are classified in the higher skill group. There are no data on current enrollment or on the duration, level or type of training in Australia within these categories. The data file includes many demographic and skill variables that serve as explanatory variables for the analysis. 
Unfortunately, it does not include data on earnings or occupation in Australia. Because of the limited geographic detail on the data file, and the small number of Australian states, it is not feasible to include region-specific variables in the analysis. The variables used in the analysis are defined in detail in Appendix A.

\section{Empirical Analysis}

The empirical estimation of the model for investment in postmigration education is presented in Table 2 for men and women combined, and separately by gender in Table 3 using ordinary least squares (OLS) and logit analysis. Tables 4 and 5 report separately by gender the multinomial logit analysis for the type of training received.

\section{(a) Determinants of Post-Migration Education}

Tables 2 and 3 analyze whether an educational qualification was obtained after immigration, where the dependent variable is unity if one was obtained. For each specification both an ordinary least squares (OLS) model and a non-linear logit model are estimated. The models are all statistically significant as measured by $F$ or $\chi^{2}$-test statistics. The oLS and logit models result in the same substantive implications, so the discussion focuses on the oLs estimates because of the ease of interpretation.

There is a strong, highly significant negative effect of age at arrival on the acquisition of post-migration training among both men and women. Compared to the benchmark, those 18 to 24 years at immigration, in the pooled ols analysis those 25 to 34 years at 
immigration were 5 percent less likely to receive such training, the 35 to 44 year olds at arrival were 11 percent less likely, and the older group (45 to 64 years) were 14 percent less likely.

Among both men and women, the longer an individual has been in Australia the more likely it is that post-migration training has been obtained. In the oLS analysis for the pooled sample, the most recent cohort (immigrated 1986-87) was 17 percent less likely to have received training than the longest duration cohort (pre-1967). The coefficients imply a non-linear effect. The probability of having acquired a qualification rises sharply in the first few years, and then rises more slowly with a longer duration in Australia.

Pre-immigration education and pre-immigration occupation have separate effects and imply a complementarity between preimmigration skills and post-migration investment. Those with an educational qualification prior to immigration were more likely to obtain one after immigration. Those in higher skilled occupations prior to immigration (i.e., professionals, managers and administrators) were more likely to obtain post-migration training than those with less-skilled occupations.

These patterns for pre-immigration education and occupation suggest that the higher the level of pre-immigration skill the greater the likely relative decline in occupational status if destination-specific qualifications are not obtained. The Australian training is highly productive for the most skilled of immigrants as it enhances the transferability of previously 
acquired skills. This is consistent with the pattern of postmigration investment and occupational change observed in the U.S. (Chiswick 1978b). It also suggests that the finding in Hashmi (1987) and Borjas (1982) of a tendency for a negative relation between pre- and post-migration education may be the spurious result of measurement error.

There appear to be differences by country of origin. Immigrants from Asia and the miscellaneous category 'other countries' are more likely to invest in training than immigrants from English-speaking countries (the benchmark) in the pooled male/female analysis. However, when the analyses are performed separately by gender, thereby reducing the sample sizes by onehalf, only males from "other countries" show a marginally significant positive effect. New zealanders show a marginally significant negative effect in the pooled analysis and among women. Those from the Mediterranean countries (Italy, Greece, Yugoslavia, Lebanon and Turkey) are substantially and significantly less likely to invest in their own training than other immigrant groups. Thus, there is a weak ranking of the non-Mediterranean countries of origin - immigrants with a non-English-speaking origin are most likely to receive training, then those of English-speaking origin, and the least training in Australia is received by the New zealanders. This suggests that skill transferability and the propensity for to and from migration (costs of migration) influence investment decisions. The strong negative effect on educational 
attainment for those of Mediterranean origin requires further research.

Gender plays a significant role. Other variables the same, including visa category, women are 4 percent less likely to have obtained post-migration training. This may reflect the weaker attachment to the labor force of women compared to men.

Visa category is also a significant determinant of investment. 4 Among men, compared to unsponsored immigrants (the benchmark), refugees are the only group that make fewer investments in training after immigration. The refugees in Australia are predominantly from South-East Asia (over half of the refugees visas issued in 1987 were to South-East Asian refugees). When separate dichotomous variables are used for Asian refugees and other refugees it is found that male Asian refugees, but not other refugees, make fewer investments in training after arrival in Australia.5 This may reflect the very poor English language fluency of the South-East Asian refugees.

Immigrant women are less likely to invest in training if they are tied movers (i.e., sponsored by a family member or their spouse is a principal applicant) compared to unsponsored immigrant women. Women sponsored by an employer are more likely to do so. Investment behavior among women who are not refugees is therefore much more sensitive to migration category that it is among men, apparently reflecting anticipated labor market status. The women in the low investment groups have labor force participation rates of about 50 percent (sponsored by family or spouse of principal 
applicant) compared to 64 percent for unsponsored immigrants and an even higher participation rate $(72$ percent $)$ for those women sponsored by an employer. ${ }^{6}$

Although in principle the causation could go from receipt of training to labor force participation, econometric analyses indicate that this effect is very small (Chiswick and Miller, 1992a). Rather, it appears that among women there are sharp differences in anticipated labor supply across the migration categories that influence post-migration investment decisions.

b) Analysis of Type of Education

The multinomial logit analyses in Tables 4 and 5 focus on the specific types of training (Degree, Trade, Certificate, Nil) that immigrants acquire. The multinomial logit technique estimates the effect of the explanatory variables on the log-odds of acquiring a particular qualification versus not acquiring any qualifications in Australia. Tables 4 and 5 report, by gender, the partial effect of a particular characteristic (e.g., age at arrival) on the distribution of immigrants across the four post-arrival qualifications categories, ceteris paribus. Other than for the distinct male advantage in the 'Trades' category, the general pattern of results is the same for males and females. The discussion therefore focuses only on the results for males.

The information in the first section of Table 4 indicates the relation between age at arrival and the predicted probability of acquiring each type of post-arrival educational qualification. It shows the predicted relative importance of the various types of 
post-arrival qualifications. Thus, 17.6 percent (=predicted probability $\times 100$ ) of those who immigrated at age 18-24 obtained an educational qualification after immigration. Almost two-thirds of those who do have a 'certificate', ten percent obtained a degree, and about one-quarter a trade qualification. The table shows the pronounced negative estimated relationship between the probability of holding each post-arrival qualification and age at arrival. Relatively few immigrants who were 35 years or older at the time of arrival acquire any educational qualifications in Australia.

The estimated importance of pre-immigration qualifications to the acquisition of qualifications after arrival in Australia is clearly evident from the second section of

Table 4. Possession of either a degree or certificate prior to arrival in Australia improves one's chance of acquiring a qualification after arrival, especially one of the same general type. However, only approximately 12 percent of those with an overseas trade qualification acquire a qualification in Australia, a figure comparable to that for individuals who did not possess qualifications at arrival (10 percent).

The major feature of the predicted distribution for the various birthplace groups (section 3 of Table 4) is the very low proportion of immigrants from the Mediterranean region acquiring qualifications of any sort in Australia. With regard to migration category (section 5 of Table 4), the two main findings are the low probability of refugees acquiring educational qualifications after arrival in Australia, and the high probability of male partners of 
female principal applicants acquiring degrees. The latter group of men is numerically small (less than two percent of the male sample) and so little emphasis should be placed on the finding. A feature of the refugee category is that they are more likely to acquire trade qualifications after arrival in Australia than any other migration category. Inclusion of separate dichotomous variables for Asian refugees and other refugees indicates that this effect is a characteristic of refugees from South-East Asia.

The final section of Table 4 presents the estimated effect of duration in Australia on the probability of having acquired an Australian qualification. For each qualification category this proportion increases with duration in Australia, where the rate of increase is greatest in the first few years.

\section{Conclusion}

This study has been concerned with identifying the determinants of the acquisition of education by adults after immigration. The empirical estimation is based on data for Australia. Pre-immigration factors, category of admission and post-immigration influences affect the propensity to acquire Australian education.

It is shown that females are less likely than males to acquire post-migration training and that among women those who were tied movers (as indicated by migration category) had the lowest probability. The age effect arises from the lower opportunity costs among the young, their longer remaining working life and the 
incentive to make profitable investments sooner rather than later. Possession of educational qualifications before migration has a strong positive influence on acquiring qualifications after arrival in Australia. This suggests that the finding of a negative relationship in previous studies using U.S. data may be a consequence of measurement error in these studies which creates a spurious negative correlation between pre- and post-migration schooling.

The occupation held just prior to migration is also an important determinant of the probability of acquiring qualifications after arrival in Australia. Those who worked in the most skilled occupations (Professional and Managerial), have a higher probability of acquiring a qualification after immigration than any of the other groups.

Immigrants from the Mediterranean region are less likely to undertake investments in education after arrival in Australia than other birthplace groups. Among other countries of origin, postmigration training is related to transferability of skills across countries and the ease of to and from migration.

The effect of migration category on the propensity to have invested was also studied. It is found that among men, Southeast Asian refugees have a low probability of making these investments. Among women the investment probabilities are lowest for tied movers and highest for those sponsored by an employer. This pattern for women appears to be a consequence of anticipated labor force participation. 
Post-immigration influences are captured in the analysis by the variable for year of immigration. The longer an immigrant has been in Australia, the more likely it is that he or she will have acquired an Australian qualification, but the partial effect of duration is largest in the first few years and diminishes thereafter. Duration measures an exposure effect. It also reflects selectivity bias; those who intend to remain and do in fact remain are more likely to make investments specific to the destination.

This analysis demonstrates that post-migration investment decisions can be subject to systematic analysis. It indicates that pre-immigration factors are very important determinants of postmigration decisions which themselves have important impacts on labor market success. One important finding is the complementarity of pre- and post-migration investments in training. The preimmigration factors can be observed by immigration authorities when visas are issued and can be used to play an even more important role than under current policy in allocating visas to those most likely to have a successful labor market adjustment. 
1. A third study by schultz (1980) focused on the schooling of the children of adult immigrants.

2. Refugees are identified only through country of origin. Hashmi (1987) classifies all immigrants from China and cuba as refugees in her analysis of the 1976 SIE, while all immigrants from China, Cuba and Vietnam are categorized as refugees in the study of the 1980 U.S. Census. The Vietnamese were not separately identified in the $1976 \mathrm{SIE}$, and most had been in the U.S. less than one year.

3. Hashmi (1987), however, recognizes this limitation and uses an imaginative technique to correct for the bias due to the inclusion of foreign students. Foreign students were not included in the Australian survey.

4. Statistical tests indicate no significant effects of family members in Australia prior to migration, controlling for type of visa.

5. The partial regression coefficients (and t-ratios) of the refugee variables are:

\begin{tabular}{lcccc} 
& \multicolumn{2}{c}{ Males } & \multicolumn{2}{c}{ Females } \\
& OLS & LOGIT & OLS & LOGIT \\
\hline Aisan Refugee & -0.073 & -0.739 & -0.033 & -0.147 \\
& $(-2.42)$ & $(-2.32)$ & $(-0.72)$ & $(-0.23)$ \\
Other Refugee & -0.002 & -0.102 & 0.083 & 1.213 \\
& $(-0.04)$ & $(-0.78)$ & $(0.72)$ & $(1.44)$ \\
\hline \hline
\end{tabular}

6. Labor force participation rates and proportion of immigrants by migration category and by gender, 1987:

Labor Force Proportion Participation Rates of Immigrants

\section{Migration Category}

New Zealander

Refugee

Sponsored by family

Sponsored by employer

Sponsored by other

Unsponsored

Partner prin. applic. Other

Total
Males Females Total Males Females Total

\begin{tabular}{|c|c|c|c|c|c|}
\hline 33.0 & 71.3 & 82.6 & 10.7 & 9.8 & 10.3 \\
\hline D. & 66.3 & 86.3 & 6.0 & 1.3 & 3.7 \\
\hline 3.6 & 49.0 & 62.8 & 22.4 & 17.5 & 20.0 \\
\hline 7. & 71.9 & 84.7 & 7.8 & 1.7 & 4.8 \\
\hline 1 & 59.0 & 75.7 & 6.3 & 3.2 & 4.7 \\
\hline i. & 63.6 & 81.1 & 37.2 & 11.6 & 24.4 \\
\hline 0.7 & 49.5 & 51.1 & 1.9 & 46.3 & 24.0 \\
\hline & & & & & \\
\hline
\end{tabular}

$\begin{array}{llllll}84.7 & 54.6 & 69.7 & 100.0 & 100.0 & 100.0\end{array}$

Source: Labour Force status and other characteristics of Migrants, Australia, 1987. 
MAJOR FEATURES OF STUDIES OF POST-IMMIGRATION EDUCATION

IN THE UNITED STATES

Characteristics

Data

Focus

year.

Dependent Variable Years of U.S. schooling(a)

Independent

Variables

Estimation Method oIs

Major Findings
Borjas (1982)

1976 Survey of Income

\& Education (SIE)

Hispanic origin

(primarily Mexican and cuban) male immigrants aged 18-64 in paid employment

Age, location, marital status, pre-immigration schooling, birthplace, years since migration, health, school enrollment

* Negative correlation between pre-immigration and post-immigration education, i.e., the two types of education are substitutes *Cubans invest relatively more than Mexicans in U.S. schooling.

\section{Hashmi (1987)}

1976 Survey of Income \& Education; 1980 Census of Population

Foreign-born men who immigrated at age 15 or older, age 15-64 (SIE) or age 18-64 (1980 Census) in survey
Years of U.S. schooling, (a) and current enrollment status

Age, location, marital status, pre-immigration schooling, birthplace, years since migration, school cost and school quality (state level)

oLs \& Probit

* Negative correlation between pre-immigration and post-immigration education, *Post-immigration schooling declines with age at migration, rises with years since migration * Immigrants from nonEnglish speaking countries and refugees invest more in U.S. schooling than other immigrant groups.

(a) Estimated measure of years of U.S. schooling. 


$$
\text { Table } 2^{\#}
$$

ANALYSIS OF POST-IMMIGRATION EDUCATION, AUSTRALIA, 1987 (Dependent Variable: Obtained Educational Qualification)

\begin{tabular}{|c|c|c|}
\hline Constant & $\begin{array}{r}0.276 \\
\langle 16.47\rangle\end{array}$ & $\begin{array}{r}-0.839 \\
(6.78)\end{array}$ \\
\hline \multicolumn{3}{|l|}{ Age on arrival: } \\
\hline 25-34 years & $\begin{array}{l}-0.049 \\
(5.00)\end{array}$ & $\begin{array}{l}-0.394 \\
(5.05)\end{array}$ \\
\hline $35-44$ years & $\begin{array}{l}-0.106 \\
(9.75)\end{array}$ & $\begin{array}{l}-0.961 \\
(8.82)\end{array}$ \\
\hline $45-64$ years & $\begin{array}{r}-0.140 \\
(13.28)\end{array}$ & $\begin{array}{l}-1.738 \\
(9.37)\end{array}$ \\
\hline $\begin{array}{l}\text { Pre-immigration } \\
\text { qualification }\end{array}$ & $\begin{array}{r}0.072 \\
(8.32)\end{array}$ & $\begin{array}{r}0.651 \\
(8.38)\end{array}$ \\
\hline \multicolumn{3}{|l|}{ Country of birth: } \\
\hline Mediterranean & $\begin{array}{l}-0.106 \\
(10.54)\end{array}$ & $\begin{array}{l}-1.170 \\
(8.73)\end{array}$ \\
\hline Other Europe & $\begin{array}{l}-0.005 \\
(0.35)\end{array}$ & $\begin{array}{r}-0.045 \\
(0.40)\end{array}$ \\
\hline Asia & $\begin{array}{r}0.025 \\
(2.00)\end{array}$ & $\begin{array}{r}0.200 \\
(1.97)\end{array}$ \\
\hline other countries & $\begin{array}{l}0.036 \\
(1.93)\end{array}$ & $\begin{array}{r}0.293 \\
(2.11)\end{array}$ \\
\hline Female & $\begin{array}{r}-0.043 \\
(4.32)\end{array}$ & $\begin{array}{r}-0.423 \\
(4.70)\end{array}$ \\
\hline \multicolumn{3}{|c|}{ Pre-immigration occupation: } \\
\hline Tradespersons & $\begin{array}{l}-0.029 \\
(1.99)\end{array}$ & $\begin{array}{r}-0.254 \\
(2.49)\end{array}$ \\
\hline $\begin{array}{l}\text { Clerks \& } \\
\text { salespersons }\end{array}$ & $\begin{array}{l}-0.047 \\
(3.36)\end{array}$ & $\begin{array}{l}-0.325 \\
(2.95)\end{array}$ \\
\hline $\begin{array}{l}\text { Plant \& machine } \\
\text { operators etc. }\end{array}$ & $\begin{array}{l}-0.081 \\
(6.03)\end{array}$ & $\begin{array}{l}-0.742 \\
(5.48)\end{array}$ \\
\hline $\begin{array}{l}\text { No work just } \\
\text { before migration }\end{array}$ & $\begin{array}{l}-0.049 \\
(3.93)\end{array}$ & $\begin{array}{r}-0.397 \\
(3.87)\end{array}$ \\
\hline \multicolumn{3}{|l|}{ Migration category: } \\
\hline New Zealander & $\begin{array}{l}-0.016 \\
(1.02)\end{array}$ & $\begin{array}{r}-0.115 \\
(0.91)\end{array}$ \\
\hline Refugee & $\begin{array}{l}-0.051 \\
(2.36)\end{array}$ & $\begin{array}{r}-0.404 \\
(1.79)\end{array}$ \\
\hline $\begin{array}{l}\text { Sponsored by } \\
\text { family }\end{array}$ & $\begin{array}{r}-0.022 \\
(1.86)\end{array}$ & $\begin{array}{r}-0.157 \\
(1.42)\end{array}$ \\
\hline $\begin{array}{l}\text { Sponsored by } \\
\text { employer }\end{array}$ & $\begin{array}{r}0.031 \\
(1.40)\end{array}$ & $\begin{array}{r}0.160 \\
(1.18)\end{array}$ \\
\hline $\begin{array}{l}\text { Sponsored by } \\
\text { other }\end{array}$ & $\begin{array}{r}0.025 \\
(1.21)\end{array}$ & $\begin{array}{r}0.193 \\
(1.38)\end{array}$ \\
\hline
\end{tabular}


Table 2 (continued)

\begin{tabular}{lcc} 
& OLS & Logit \\
\hline Partner of & -0.028 & -0.272 \\
principal applicant & $(2.18)$ & $(2.24)$ \\
Other applicant & 0.021 & 0.181 \\
Year of arrival: & $(1.04)$ & $(1.22)$ \\
1976-1980 & -0.025 & -0.198 \\
& $(1.83)$ & $(1.90)$ \\
$1980-1982$ & -0.067 & -0.548 \\
& $(5.71)$ & $(5.13)$ \\
$1983-1985$ & -0.099 & -0.887 \\
& $(7.87)$ & $(6.58)$ \\
$1986-1987$ & -0.168 & -2.289 \\
Sample size & $(15.61)$ & $(7.63)$ \\
F & 8121 & 8121 \\
$\mathrm{R}^{2}$ & 30.888 & \\
$\chi^{2}$ & .0812 & 757.8 \\
\hline
\end{tabular}

(a) = variable not entered.

' $t$ ' statistics in parentheses.

\# The reference group is defined as male immigrants from English-speaking countries who arrived in Australia before 1976, were 18-24 years of age at the time of arrival, did not acquire a qualification before they arrived, were unsponsored, and worked in the Managerial and professional occupational group just before migration.

Source: Labour Force Status and other Characteristics of Migrants, Australia, 1987. 
Table $3^{\#}$

ANALYSIS OF POST-IMMIGRATION EDUCATION BY GENDER, AUSTRALIA, 1987

\begin{tabular}{|c|c|c|c|c|}
\hline & \multicolumn{2}{|c|}{ Males } & \multicolumn{2}{|c|}{ Females } \\
\hline & OLS & Logit & OLS & Logit \\
\hline Constant & $\begin{array}{r}0.295 \\
(13.12)\end{array}$ & $\begin{array}{l}-0.825 \\
(5.46)\end{array}$ & $\begin{array}{r}0.226 \\
(8.75)\end{array}$ & $\begin{array}{l}-1.213 \\
(5.83)\end{array}$ \\
\hline $\begin{array}{l}\text { Age on arrival: } \\
25-34 \text { years }\end{array}$ & $\begin{array}{l}-0.056 \\
(3.72)\end{array}$ & $\begin{array}{l}-0.374 \\
(3.72)\end{array}$ & $\begin{array}{l}-0.039 \\
(3.09)\end{array}$ & $\begin{array}{l}-0.366 \\
(2.90)\end{array}$ \\
\hline $35-44$ years & $\begin{array}{l}-0.135 \\
(8.07)\end{array}$ & $\begin{array}{l}-0.985 \\
(7.23)\end{array}$ & $\begin{array}{l}-0.070 \\
(5.05)\end{array}$ & $\begin{array}{l}-0.786 \\
(4.29)\end{array}$ \\
\hline $45-64$ years & $\begin{array}{l}-0.171 \\
(9.57)\end{array}$ & $\begin{array}{l}-1.522 \\
(6.99)\end{array}$ & $\begin{array}{l}-0.109 \\
(9.07)\end{array}$ & $\begin{array}{l}-2.120 \\
(5.70)\end{array}$ \\
\hline $\begin{array}{l}\text { Pre-immigration } \\
\text { qualification }\end{array}$ & $\begin{array}{c}0.064 \\
(4.85)\end{array}$ & $\begin{array}{r}0.473 \\
(4.63)\end{array}$ & $\begin{array}{c}0.078 \\
(6.67)\end{array}$ & $\begin{array}{r}0.839 \\
(6.88)\end{array}$ \\
\hline $\begin{array}{l}\text { Country of birth: } \\
\text { Mediterranean }\end{array}$ & $\begin{array}{r}-0.123 \\
(7.69)\end{array}$ & $\begin{array}{l}-1.011 \\
(6.45)\end{array}$ & $\begin{array}{r}-0.092 \\
(7.74)\end{array}$ & $\begin{array}{l}-1.607 \\
(5.90)\end{array}$ \\
\hline Other Europe & $\begin{array}{l}0.009 \\
(0.39)\end{array}$ & $\begin{array}{l}0.046 \\
(0.33)\end{array}$ & $\begin{array}{l}-0.020 \\
(1.19)\end{array}$ & $\begin{array}{l}-0.191 \\
(1.02)\end{array}$ \\
\hline Asia & $\begin{array}{r}0.025 \\
(1.25)\end{array}$ & $\begin{array}{r}0.170 \\
(1.23)\end{array}$ & $\begin{array}{r}0.020 \\
(1.27)\end{array}$ & $\begin{array}{r}0.159 \\
(1.06)\end{array}$ \\
\hline other countries & $\begin{array}{r}0.050 \\
(1.72)\end{array}$ & $\begin{array}{l}0.341 \\
(1.87)\end{array}$ & $\begin{array}{l}0.021 \\
(0.91)\end{array}$ & $\begin{array}{r}0.198 \\
(0.92)\end{array}$ \\
\hline $\begin{array}{l}\text { Pre-immigration occupa } \\
\text { Tradespersons }\end{array}$ & $\begin{array}{l}\text { ion: } \\
\quad-0.025 \\
(1.46)\end{array}$ & $\begin{array}{l}-0.171 \\
(1.50)\end{array}$ & $\begin{array}{l}-0.054 \\
(1.78)\end{array}$ & $\begin{array}{l}-0.390 \\
(1.29)\end{array}$ \\
\hline $\begin{array}{l}\text { Clerks \& } \\
\text { salespersons }\end{array}$ & $\begin{array}{l}-0.056 \\
(2.58)\end{array}$ & $\begin{array}{l}-0.388 \\
(2.34)\end{array}$ & $\begin{array}{r}-0.047 \\
(2.37)\end{array}$ & $\begin{array}{l}-0.365 \\
(2.33)\end{array}$ \\
\hline $\begin{array}{l}\text { Plant \& machine } \\
\text { operators etc. }\end{array}$ & $\begin{array}{l}-0.080 \\
(4.45)\end{array}$ & $\begin{array}{l}-0.627 \\
(4.11)\end{array}$ & $\begin{array}{l}-0.093 \\
(4.84)\end{array}$ & $\begin{array}{l}-1.321 \\
(3.87)\end{array}$ \\
\hline $\begin{array}{l}\text { No work just } \\
\text { before migration }\end{array}$ & $\begin{array}{l}-0.041 \\
(2.18)\end{array}$ & $\begin{array}{l}-0.277 \\
(2.00)\end{array}$ & $\begin{array}{l}-0.057 \\
(3.13)\end{array}$ & $\begin{array}{l}-0.464 \\
(2.94)\end{array}$ \\
\hline $\begin{array}{l}\text { Migration category: } \\
\text { New Zealander }\end{array}$ & $\begin{array}{c}0.004 \\
(0.19)\end{array}$ & $\begin{array}{l}0.028 \\
(0.18)\end{array}$ & $\begin{array}{l}-0.040 \\
(1.69)\end{array}$ & $\begin{array}{l}-0.325 \\
(1.45)\end{array}$ \\
\hline Refugee & $\begin{array}{l}-0.051 \\
(1.93)\end{array}$ & $\begin{array}{l}-0.466 \\
(1.83)\end{array}$ & $\begin{array}{l}-0.008 \\
(0.17)\end{array}$ & $\begin{array}{l}0.228 \\
(0.44)\end{array}$ \\
\hline $\begin{array}{l}\text { Sponsored by } \\
\text { family }\end{array}$ & $\begin{array}{l}-0.011 \\
(0.69)\end{array}$ & $\begin{array}{l}-0.094 \\
(0.73)\end{array}$ & $\begin{array}{l}-0.034 \\
(1.77)\end{array}$ & $\begin{array}{l}-0.293 \\
(1.41)\end{array}$ \\
\hline $\begin{array}{l}\text { Sponsored by } \\
\text { employer }\end{array}$ & $\begin{array}{l}0.012 \\
(0.49)\end{array}$ & $\begin{array}{r}0.079 \\
(0.52)\end{array}$ & $\begin{array}{r}0.147 \\
(2.67)\end{array}$ & $\begin{array}{r}0.846 \\
(2.76)\end{array}$ \\
\hline $\begin{array}{l}\text { Sponsored by } \\
\text { other }\end{array}$ & $\begin{array}{r}0.040 \\
(1.56)\end{array}$ & $\begin{array}{r}0.270 \\
(1.68)\end{array}$ & $\begin{array}{l}-0.008 \\
(0.26)\end{array}$ & $\begin{array}{r}0.009 \\
(0.03)\end{array}$ \\
\hline $\begin{array}{l}\text { Partner of } \\
\text { principal applicant }\end{array}$ & $\begin{array}{r}0.051 \\
(1.19)\end{array}$ & $\begin{array}{c}0.416 \\
(1.24)\end{array}$ & $\begin{array}{l}-0.041 \\
(2.26)\end{array}$ & $\begin{array}{l}-0.372 \\
(2.31)\end{array}$ \\
\hline
\end{tabular}


Table 3 (continued)

\begin{tabular}{lcccc} 
Other applicant & 0.036 & 0.229 & 0.006 & 0.139 \\
$\begin{array}{l}\text { Year of arrival: } \\
1976-1980\end{array}$ & $(1.17)$ & $(1.18)$ & $(0.21)$ & $(0.58)$ \\
& -0.054 & -0.363 & -0.001 & -0.044 \\
$1980-1982$ & $(2.70)$ & $(2.59)$ & $(0.02)$ & $(0.28)$ \\
& -0.081 & -0.538 & -0.055 & -0.592 \\
$1983-1985$ & $(4.36)$ & $(3.92)$ & $(3.84)$ & $(3.44)$ \\
& -0.122 & -0.905 & -0.082 & -0.926 \\
$1986-1987$ & $(6.12)$ & $(5.06)$ & $(5.23)$ & $(4.42)$ \\
& -0.212 & -2.368 & -0.137 & -2.329 \\
Sample size & $(12.27)$ & $(6.00)$ & $(9.78)$ & $(5.00)$ \\
F & 4058 & 4058 & 4063 & 4063 \\
$\mathrm{R}^{2}$ & 13.848 & & 16.674 & \\
$\chi^{2}$ & .0679 & & & \\
\hline \# For notes to Table, see Table 2. & & & 891.4 \\
\hline
\end{tabular}




\section{PREDICTED PROBABILITIES OF IMMIGRANTS ACQUIRING PARTICULAR TYPES OF POST-ARRIVAL QUALIFICATIONS BY VARIOUS CHARACTERISTICS, OTHER VARIABLES HELD CONSTANT, MALES, AUSTRALIA}

Characteristic

$$
\text { Degree }
$$

Trade

Certificate

$\mathrm{Nil}$

1. Age on arrival

$18-24$

0.018

0.046

0.008

0.037

0.112

0.824

$25-34$

0.006

0.024

0.085

0.871

$35-44$

0.003

0.008

0.043

0.927

$45-64$

0.040

0.015

0.037

0.952

2. Pre-immigration qualification

$\begin{array}{ll}\text { Degree } & 0.040 \\ \text { Trade } & 0.004 \\ \text { Certificate } & 0.012 \\ \text { Nil } & 0.010\end{array}$

0.047

0.103

0.842

0.070

0.878

Nil

0.030

0.153

0.811

3. Birthplace

English-speaking countries

0.011

0.034

0.059

0.901

Mediterranean

0.001

0.018

0.090

0.865

Other Europe

0.008

0.042

0.030

0.951

Asia

0.018

0.035

0.087

0.863

other countries

0.027

0.038

0.090

0.857

4. Pre-immigration occupation Managerial \& professional

0.020

0.023

0.103

0.832

Trades

0.005

0.057

0.090

0.867

Clerical \& sales

0.007

0.015

0.077

0.861

Plant \& machine operator

0.004

0.029

0.088

0.890

No work just before migration

0.016

0.032

0.056

0.911

5. Migration category

New Zealander

0.012

0.040

0.069

0.883

Refugee

Sponsored by family

0.001

0.052

0.074

0.874

0.008

0.040

0.044

0.903

Sponsored by employer

0.020

0.020

0.067

0.885

Sponsored by other

0.007

0.043

0.073

0.887

Partner of prin. applicant

0.011

0.000

0.116

0.833

Other applicant

0.014

0.043

0.150

0.838

Unsponsored

0.009

0.040

0.090

0.854

6. Year of arrival

Pre-1976

1976-1979

1980-1982

1983-1985

1986-1987

\begin{tabular}{llll}
0.013 & 0.050 & 0.093 & 0.844 \\
0.009 & 0.033 & 0.070 & 0.888 \\
0.011 & 0.018 & 0.071 & 0.901 \\
0.002 & 0.016 & 0.058 & 0.924 \\
0.001 & 0.003 & 0.014 & 0.982 \\
\hline
\end{tabular}

Calculations refer to immigrants who have the mean value of all

characteristics other than for the category under consideration in any section of the table.

Note: Entries in a row may not sum to 1.000 due to rounding. 
Table 5

PREDICTED PROBABILITIES OF IMMIGRANTS ACQUIRING PARTICULAR TYPES OF POST-ARRIVAL QUALIFICATIONS BY VARIOUS CHARACTERISTICS, OTHER VARIABLES HELD CONSTANT, FEMALES, AUSTRALIA

\begin{tabular}{lcccc} 
Characteristic & Degree & Trade & Certificate & Nil \\
\hline 1. Age on arrival & & & & \\
$18-24$ & 0.001 & 0.000 & 0.083 & 0.915 \\
$25-34$ & 0.001 & 0.000 & 0.062 & 0.937 \\
$35-44$ & 0.000 & 0.000 & 0.042 & 0.957 \\
$45-64$ & 0.000 & 0.000 & 0.012 & 0.988
\end{tabular}

2. Pre-immigration qualification

$\begin{array}{lllll}\text { Degree } & 0.004 & 0.000 & 0.092 & 0.904 \\ \text { Trade } & 0.001 & 0.000 & 0.057 & 0.942 \\ \text { Certificate } & 0.001 & 0.000 & 0.089 & 0.910 \\ \text { Nil } & 0.001 & 0.000 & 0.041 & 0.958\end{array}$

3. Birthplace

$\begin{array}{lllll}\text { English-speaking countries } & 0.001 & 0.000 & 0.067 & 0.931 \\ \text { Mediterranean } & 0.000 & 0.000 & 0.014 & 0.986 \\ \text { Other Europe } & 0.000 & 0.000 & 0.063 & 0.936 \\ \text { Asia } & 0.001 & 0.000 & 0.080 & 0.919 \\ \text { Other countries } & 0.003 & 0.000 & 0.071 & 0.927\end{array}$

4. Pre-immigration occupation Managerial \& professional

Trades

0.002

0.000

0.078

0.921

Clerical \& sales

0.001

0.000

0.054

0.945

Plant \& machine operator

0.000

0.000

0.064

0.935

No work just before migration

0.001

0.000

0.019

0.980

5. Migration category

New Zealander

0.001

0.000

0.055

0.945

Refugee

0.001

0.000

0.051

0.948

Sponsored by family

0.001

0.000

0.077

0.920

Sponsored by employer

0.003

0.000

0.059

0.941

Sponsored by other

0.000

0.000

0.144

0.854

Partner of prin. applicant

0.002

$0 \quad 000$

0.063

0.936

other applicant

0.001

0.000

0.046

0.953

Unsponsored

0.001

0.000

0.074

0.925

6. Year of arrival

Pre-1976

1976-1979

0.008

0.001

0.064

0.935

1980-1982

0.013

0.000

0.072

0.920

0.003

0.000

0.061

0.926

1983-1985

0.000

0.000

0.042

0.955

1986-1987

0.000

0.000

0.036

0.964

0.009

0.991

Calculations refer to immigrants who have the mean value of all characteristics other than for the category under consideration in any section of the table.

Note: Entries in a row may not sum to 1.000 due to rounding. 


\section{Appendix A: Definitions of the Variables}

(*Designates benchmark group)

Year of arrival: 5 categories: (i) arrived before $1976^{*}$ arrived 1976-79, (iii) arrived 1980-82, (iv) arrived 1983-85, (v) arrived 1986-87.

Age at arrival: The analysis is restricted to individuals age 18-64 at immigration. Four age at arrival groups are used: (i) $18-24^{*}$, (ii) 25-34, (iii) 35-44, (iv) 45-64.

Birthplace: The birthplaces are aggregated into five groups: (i) English-speaking countries [United States, Canada, United Kingdom, Ireland, New Zealand, Republic of South Africa]"

Mediterranean [Greece, Italy, Yugoslavia, Lebanon and Turkey], (iii) Other Europe [Germany, Poland, Other Europe], (iv) Asia [India, Malaysia, Vietnam, Other Asia], (v) other [Other Africa, Other America, Other Oceania].

Pre-immigration occupation: Five categories (i) Managers, administrators, professionals and para-professionals*,

Tradespersons, (iii) Clerks, salespersons and personal service workers, (iv) Plant and machine operators and drivers, laborers and related workers, (v) Did not have a job just before migration. 
Pre-immigration educational attainment: (a) Possession of preimmigration educational qualifications: if yes $=1$, zero otherwise*. (b) Type of pre-arrival qualification: (i) Degree, (ii) Trade qualification, (iii) Certificate, diploma or other qualification, (iv) no qualifications*.

Migration category: An adult immigrant to Australia may enter as a New Zealander, a principal applicant, the partner (spouse) of a principal applicant, or as an other applicant. Principal applicants may enter as refugees, sponsored migrants or unsponsored migrants. Individuals can be sponsored by family members, an employer or by some other group, where the sponsor is an Australian resident. Thus, there are eight mutually exclusive migration categories: (i) New Zealander, (ii) Refugee, (iii) sponsored by family, (iv) sponsored by employer, (v) sponsored by other organization, (vi) Unsponsored*, (vii) Partner of principal applicant, (viii) other applicant.

Gender: Dichotomous variable, 1 = female, $0=$ male. Note: Survey conducted March 1987.

Source: Australian Bureau of Statistics (1987) Labour Force Status and other Characteristics of Migrants, Australia. 
APPENDIX TABLE 1

MEANS AND STANDARD DEVIATIONS OF VARIABLES BY GENDER

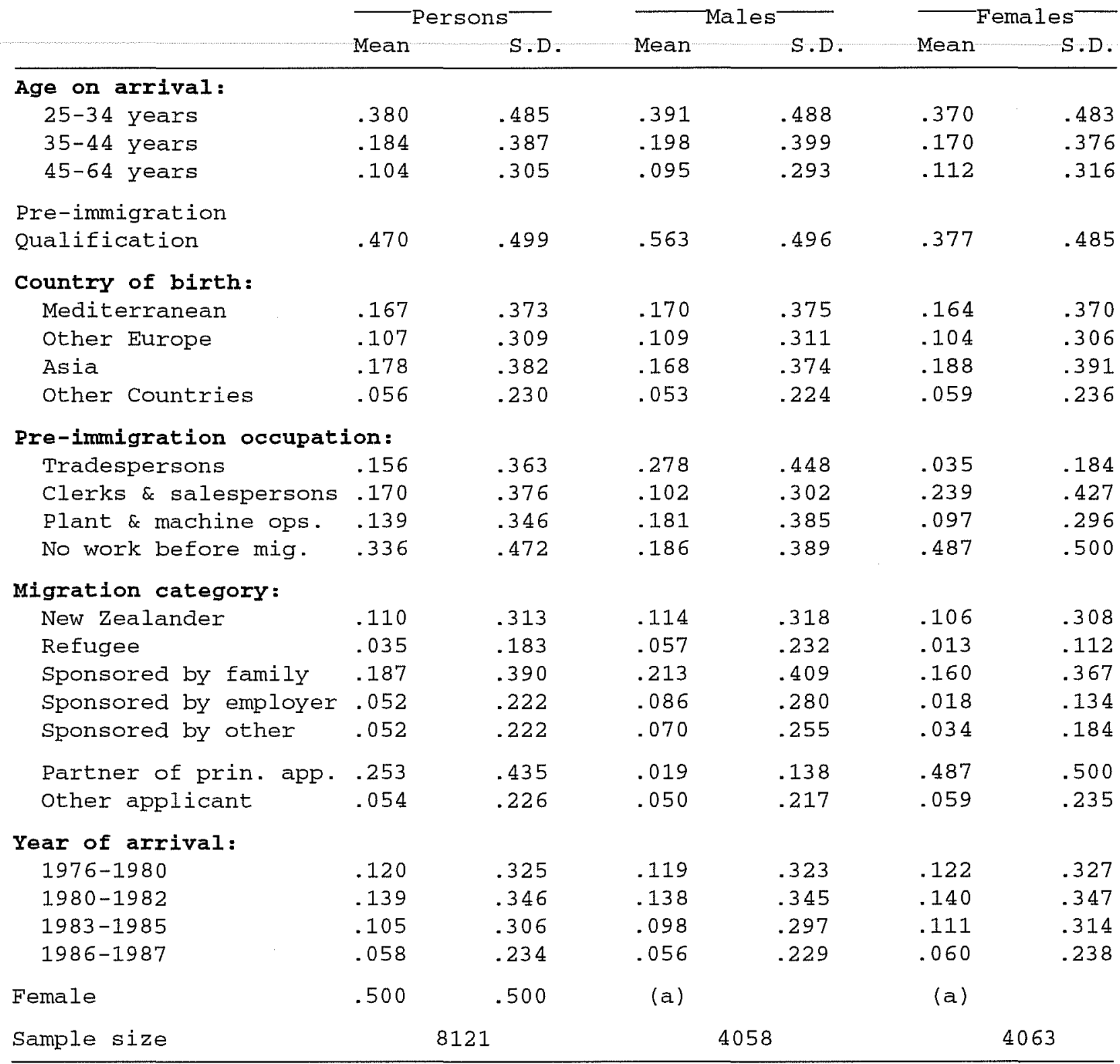

S.D. = standard deviation

source: Labour Force Status and other Characteristics of Migrants, Australia, 1987. 


\section{References}

Australian Bureau of Statistics, (1987). Labour Force Status and other Characteristics of Migrants, Australia, March 1987, Catalogue No. 6250.0, Canberra: Commonwealth Government Printer.

Borjas, George J., (1982). "The Earnings of Male Hispanic Immigrants in the United states", Industrial and Labor Relations Review, Vol. 35, No. 3, pp. 343-353.

Chiswick, Barry R., (1978a) "The Effect of Americanization on the Earnings of Foreign-Born Men", Journal of Political Economy, Vol. 86, No. 5, (October) pp. 897-921.

Chiswick, Barry R., (1978b). "A Longitudinal Analysis of the Occupational Mobility of Immigrants", in Barbara Dennis (ed.) Proceedings of the Thirtieth Annual Winter Meetings, Industrial Relations Research Association, Madison, IRRA, pp. 20-27.

Chiswick, Barry R., (1979). "The Economic Progress of Immigrants: Some Apparently Universal Patterns", in William Fellner (ed.) Contemporary Economic Problems, 1979, Washington: American Enterprise Institute, pp. 357-399.

Chiswick, Barry R. and Paul w. Miller, (1985). "Immigrant Generation and Income in Australia", Economic Record, Vol. 61, No. 173, pp. 540-553.

Chiswick, Barry R. and Paul W. Miller, (1992a). Post-Immigration Qualifications in Australia, Australian Government Publishing Service, Canberra.

Chiswick, Barry R. and Paul w. Miller, (1992b). "The Endogeneity Between Language and Earnings", mimeo, Department of Economics, The University of Western Australia.

Committee to Advise on Australia's Immigration Policies, (1988). Immigration: A Commitment to Australia, The Report of the Committee to Advise on Australia's Immigration Policies, [Chairman: Stephen Fitzgerald], Canberra: Australian Government Publishing service.

Hashmi, Aliya, (1987) . Post-Migration Investment in Education by Immigrants in the United states, unpublished Ph.D. dissertation, The University of Illinois at Chicago, Chicago, Illinois. 
Miller, Paul and Paul Volker (1989). "Socioeconomic Influences on Educational Attainment: Evidence and Implications for the Tertiary Education Finance Debate", The Australian Journal of Statistics, Special Volume 31A, pp. 47-70.

Schultz, T. Paul (1980) "The Schooling and Health of Children of Immigrants" Appendix U.S. Immigration Policy and the National Interest, Staff Report of the Select Commission on Immigration and Refugee Policy, U.s. Government Printing office, Washington, DC.

Wooden, Mark (1989). "Migrant Labour Market Status: The Role of Migration Category", Paper presented to the Economic Society of Australia, Annual Conference, Adelaide, July 1989.

Wooden, Mark (1990). Migrant Labour Market Status, Australian Government Publishing Service, Canberra. 